\title{
MENGGERAKKAN LITERASI BACA-TULIS DI RUSUNAWA MUARA BARU PLUIT
}

\author{
Sri Hapsari Wijayanti ${ }^{1}$, Novia Utami ${ }^{2}$, Adji Pratikto ${ }^{3}$, Hery Pramono ${ }^{4}$
}

\author{
${ }^{1}$ Fakultas Ekonomi dan Bisnis, Universitas Katolik Indonesia Atma Jaya \\ Email: sri.hapsari@atmajaya.ac.id \\ ${ }^{2}$ Fakultas Ekonomi dan Bisnis, Universitas Katolik Indonesia Atma Jaya \\ Email: novia.utami@atmajaya.ac.id \\ ${ }^{3}$ Fakultas Ekonomi dan Bisnis, Universitas Katolik Indonesia Atma Jaya \\ Email: adji.pratikto@atmajaya.ac.id \\ ${ }^{4}$ Fakultas Ekonomi dan Bisnis, Universitas Katolik Indonesia Atma Jaya \\ Email: herry.pramono29@gmail.com
}

\begin{abstract}
ABSTRAK
Pemerintah telah menggulirkan Gerakan Literasi Nasional (GLN) sejak 2015. Salah satu sentra belajar di masyarakat yang mendukung GLN adalah pendirian Ceribel di Rusunawa Muara Baru, Pluit, Jakarta Utara. Tujuan kegiatan di Rusunawa Muara Baru ini adalah menggerakkan literasi baca-tulis melalui pelayanan kepada anak-anak untuk datang dan melakukan kegiatan positif dan kompetitif selama masa liburan sekolah. Selain itu, anak-anak yang berkunjung juga dimintai umpan balik terhadap kegiatan yang telah dilakukan di Taman Ceribel untuk menindaklanjuti kegiatan literasi pada masa mendatang. Kegiatan dilakukan selama Juni-Juli 2019. Selama periode itu, Ceribel melayani pengunjung selama sepuluh hari. Metode yang digunakan dalam kegiatan ini adalah pelayanan dalam peminjaman buku dan pendampingan dalam menulis, membaca, dan menggambar dalam rangka mengikuti lomba literasi. Pengamatan langsung juga dilakukan terhadap aktivitas pengunjung di Ceribel. Hasil kuesioner tentang umpan balik kegiatan disajikan dalam bentuk persentase yang ditabulasikan dan dideskripsikan. Semua responden, yang berjumlah delapan belas anak, mengakui merasakan manfaat dengan adanya Ceribel sebagai sumber belajar untuk menjadikan mereka pintar. Mereka berharap Ceribel dapat membantu mereka dalam belajar membaca dan bimbingan belajar. Waktu buka pelayanan operasional Ceribel menurut responden sebaiknya setiap hari. Mereka mengakui akan datang kembali ke Ceribel dengan mengajak teman. Disimpulkan bahwa Ceribel telah menarik perhatian anak-anak Rusunawa Muara Baru sebagai tempat bermain, belajar, dan bersosialisasi. Untuk itu, kegiatan literasi ini harus berkesinambungan agar tumbuh minat dan budaya membaca di masyarakat. Disarankan agar Ceribel memiliki sukarelawan dari warga rusun sendiri yang dapat melayani dan mengembangkan Ceribel.
\end{abstract}

Kata kunci: Rusunawa; Gerakan Literasi Nasional; sentra belajar; budaya baca; minat baca

\section{PENDAHULUAN}

Pada tahun 2016 Kemendikbud menggulirkan Gerakan Literasi Nasional (GLN). Tujuan gerakan ini adalah meningkatan kualitas hidup, daya saing, pengembangan karakter bangsa, serta melihat perkembangan keterampilan dan kompetensi yang dibutuhkan pada abad ke-21 sehingga diharapkan indeks literasi nasional meningkat (Atmazaki, dkk. 2017). Ranah gerakan ini meliputi ranah masyarakat, sekolah, dan keluarga. Di ranah masyarakat, gerakan literasi berbasis masyarakat sudah banyak ditemukan, seperti adanya taman baca masyarakat (TBM), rumah pintar, atau perpustakaan (umum) daerah. Perpustakaan berbasis masyarakat berfungsi sebagai sumber belajar dan menggali ilmu dan keterampilan. Karena milik bersama, masyarakat mempunyai tanggung jawab, wewenang, dan hak untuk mengelola dan mengembangkannya (Sutarno, 2006) sehingga masyarakat memiliki rasa ikut memiliki, ikut bertanggung jawab, dan ikut memelihara (Yanto, Rodiah, \& Lusiana, 2016).

Literasi baca-tulis adalah "pengetahuan dan kecakapan untuk membaca, menulis, mencari, menelusuri, mengolah, dan memahami informasi untuk menganalisis, menanggapi, dan menggunakan teks tertulis untuk mencapai tujuan, mengembangkan pemahaman dan potensi, serta 
untuk berpartisipasi di lingkungan sosial" (Kemendikbud, 2017, p.7). Literasi ini penting dibiasakan pada anak sejak prasekolah. Pada masa ini, lingkungan keluarga memegang peran penting dalam membiasakan membaca dan menumbuhkan minat membaca. Sayangnya, tidak semua keluarga memerhatikan pentingnya literasi mendasar ini, padahal membaca merupakan keterampilan berbahasa yang perlu dilatih terus-menerus melalui seringnya banyak membaca (Chairunnisa, 2017) dan untuk mewujudkannya diperlukan upaya maksimal melalui pemupukan kebiasaan sejak dini (Asdam, 2015). Peran orang tua agar anak gemar membaca bukan hanya menyuruh membaca, melainkan juga memberikan contoh dan melakukan aktivitas membaca bersama.

Selain lingkungan keluarga, lingkungan masyarakat juga dapat mendukung gerakan literasi bacatulis. Salah satu sentra belajar berbasis masyarakat yang telah diresmikan sejak 2018 ada di Rusunawa (rumah susun sederhana sewa) Muara Baru, Pluit, Kecamatan Penjaringan, Jakarta Utara. Sentra belajar, yang dinamakan Taman Ceribel (cerita dan belajar), ini didirikan atas kerja sama Unika Atma Jaya dan Coca Cola Foundation Indonesia yang telah dirintis sejak 2017. Ceribel menempati teras lantai dasar Blok 5 seluas 5 × $6 \mathrm{~m} 2$ dan dilengkapi dengan perlengkapan belajar, seperti meja belajar lipat, karpet biru, alat permainan edukatif dan interaktif, dengan beragam jenis buku dan majalah. Seperti umumnya ruang publik, Ceribel merupakan pusat sumber belajar yang memberikan fasilitas atau kemudahan belajar warga, dengan berbagai jenis sumber belajar dikembangkan dan dikelola untuk membantu meningkatkan efektivitas dan efisiensi kegiatan pembelajaran (Sukorini, 2007). Ceribel dibangun dengan konsep kenyamanan, kebersamaan, dan kekeluargaan untuk semua warga. Kenyamanan berarti sebagai ruang publik, pengunjung dapat memanfaatkan fasilitas yang ada sehingga pengunjung betah dan senang berada di sana. Kebersamaan berarti Ceribel merupakan fasilitas untuk digunakan bersama-sama dan untuk itu perlu ada rasa saling memiliki, saling merawat, dan saling menjaga baik dari segi fisik maupun perlengkapan yang ada di dalamnya. Kekeluargaan berarti Ceribel merangkul semua warga layaknya keluarga besar untuk bergandengan tangan dan bergotong royong mengembangkan Ceribel.

Ceribel telah memiliki pengurus yang berjumlah enam orang dan berasal dari para ibu rumah tangga. Ceribel bukan saja sebagai tempat berkumpul, melainkan juga tempat menikmati bacaan selayaknya taman baca. Seperti telah disepakati bersama pengurus, Ceribel diperuntukkan sebagai wadah untuk menumbuhkan minat baca warga, baik anak-anak, remaja, maupun orang dewasa; mendukung prestasi belajar sekolah bagi siswa di Rusunawa Muara Baru; menjadi sarana berkumpul warga Rusunawa Muara Baru dan sarana fasilitas acara warga; menjadi wahana edukatif, rekreatif, dan bermain warga Rusunawa Muara Baru; memfasilitasi kebutuhan pengembangan diri warga Rusunawa Muara Baru (anak, remaja, dan dewasa), yaitu tempat menyelenggarakan pelatihan, penyuluhan, dan seminar, dan sebagainya.

Meskipun sudah berjalan dua tahun, aktivitas yang dilakukan di Ceribel belum berjalan dengan maksimal, khususnya dalam pemanfaatan Ceribel sebagai taman baca atau perpustakaan masyarakat. Kegiatan di Ceribel masih dimotori oleh Unika Atma Jaya dengan kegiatan yang melibatkan para ibu rusunawa untuk kegiatan keterampilan dan parenting, tetapi belum banyak menyentuh anak-anak untuk mengajak mereka memanfaatkan koleksi di Ceribel. Aneka buku cerita anak-anak yang tersedia di Ceribel menjadi bacaan penumbuh karakter yang seharusnya dimanfaatkan secara optimal. Belum banyak anak-anak yang mengetahui apa isi koleksi Ceribel karena Ceribel tidak rutin dibuka setiap hari oleh pengurus. Karena kegiatan literasi membaca perlu ditumbuhkan sejak dini, target kegiatan ini adalah anak-anak. Oleh sebab itu, tujuan kegiatan pengabdian kepada masyarakat ini adalah menggerakkan literasi baca-tulis melalui pelayanan Ceribel kepada masyarakat, khususnya anak-anak di Rusunawa Muara Baru, untuk datang membaca dan melakukan aktivitas positif yang bersifat kompetisi. Di samping itu, pada akhir 
kegiatan, diadakan umpan balik terhadap kegiatan yang telah dilakukan untuk menindaklajuti kegiatan literasi pada masa mendatang mengingat gerakan literasi tidak dapat terbangun dalam wakut singkat, tetapi melalui proses berkesinambungan.

\section{METODE KEGIATAN}

Kegiatan ini dilaksanakan pada masa liburan sekolah semester genap 2018 pada Juni-Juli 2019. Pada masa tersebut, Ceribel melayani pengunjung hampir setiap hari pukul 09.00 sampai dengan 12.00 WIB dan/atau 13.00 sampai 15.00 WIB. Metode kegiatan yang digunakan adalah pelayanan dalam peminjaman buku untuk dibaca di tempat dan pendampingan dalam lomba. Pengunjung anak-anak dan remaja dibimbing dalam mengasah kemampuan berpikir dan berkreativitas untuk mengikuti lomba menulis tentang "Aku dan Rusunawa", lomba menggambar dan mewarnai, dan lomba puzzle. Untuk setiap kegiatan lomba disusun instrumen penilaian yang memuat unsur-unsur beserta bobotnya. Untuk lomba mengarang, kriterianya adalah kesesuaian tema, alur cerita, sistematika, bahasa, dan kerapian. Untuk lomba puzzle meliputi kecepatan waktu dan kecekatan menata puzzle; setiap peserta beradu cepat membentuk tiga gambar, yaitu binatang, buah, dan kendaraan.

Selain itu, dilakukan pengamatan langsung terhadap aktivitas pengunjung di Ceribel dan pengamatan terhadap pengunjung yang paling literat di Ceribel selama periode Juni--Juli 2019. Semua kegiatan diuraikan secara deskriptif seperti apa yang diamati. Pada dua hari terakhir sebelum lomba, pengunjung anak-anak dan remaja diberikan kuesioner berisi tentang umpan balik kegiatan di Ceribel. Hasil kuesioner dianalisis secara deskriptif kualitatif dan kuantitatif.

\section{HASIL DAN PEMBAHASAN}

Selama bulan Juni dan Juli 2019, Ceribel dibuka untuk dikunjungi anak-anak. Anak-anak datang ke Ceribel baik sendiri maupun bersama dengan temannya. Bahkan, ada yang diantar orang tuanya. Orang tua, khususnya ibu, mengawasi anak mereka dari balik jendela kaca sebelum kemudian meninggalkan anaknya di Ceribel untuk kembali ke rumah. Berikut jumlah pengunjung yang datang ketika jam buka Ceribel (Tabel 1).

Tabel 1. Pengunjung Ceribel

\begin{tabular}{ccc}
\hline No. & $\begin{array}{c}\text { Hari, tanggal } \\
\text { (2019) }\end{array}$ & $\begin{array}{c}\text { Jumlah pengunjung } \\
\text { (orang) }\end{array}$ \\
\hline 1 & Rabu, 26 Juni & 26 \\
2 & Sabtu, 29 Juni & 26 \\
3 & Senin, 1 Juli & 18 \\
4 & Rabu, 3 Juli & 19 \\
5 & Kamis, 4 Juli & 15 \\
6 & Jumat, 5 Juli & 4 \\
7 & Sabtu, 6 Juli & 23 \\
8 & Senin, 8 Juli & 7 \\
9 & Rabu, 10 Juli & 11 \\
10 & Kamis, 11 Juli & 9 \\
\hline
\end{tabular}

Dilihat dari Tabel 1, jumlah pengunjung Ceribel tidak menentu. Pertama Ceribel buka dan pada hari Sabtu jumlah pengunjung lebih banyak dari hari-hari lainnya meskipun saat itu anak-anak sedang liburan sekolah. Jumlah ini makin berkurang menjelang masuk sekolah pada 15 Juli 2019. Tim dibantu oleh dua mahasiswa sebagai asisten yang melakukan pendampingan rutin. Mereka melayani anak-anak yang datang ke Ceribel untuk mencari buku, meminjam buku, bermain bersama, atau belajar. Di Ceribel tersedia lebih dari 500 buku dan majalah. Buku pelajaran sekolah, 
buku cerita, buku cerita bergambar, cerpen, novel, pengetahuan umum, autobiografi, agama, hingga majalah anak-anak, remaja tersedia di Ceribel. Selain itu, dilengkapi pula dengan permainan kreatif dan edukatif, seperti APE (alat permainan edukatif) untuk anak-anak usia dini (AUD), lego, monopoli, puzzle, boneka, dan boneka tangan. Siapa pun yang datang wajib mengisi buku tamu sehingga dapat dimonitor jumlah pengunjung setiap hari. Gambar 1, menunjukkan aktivitas anak dalam bermain di Ceribel.
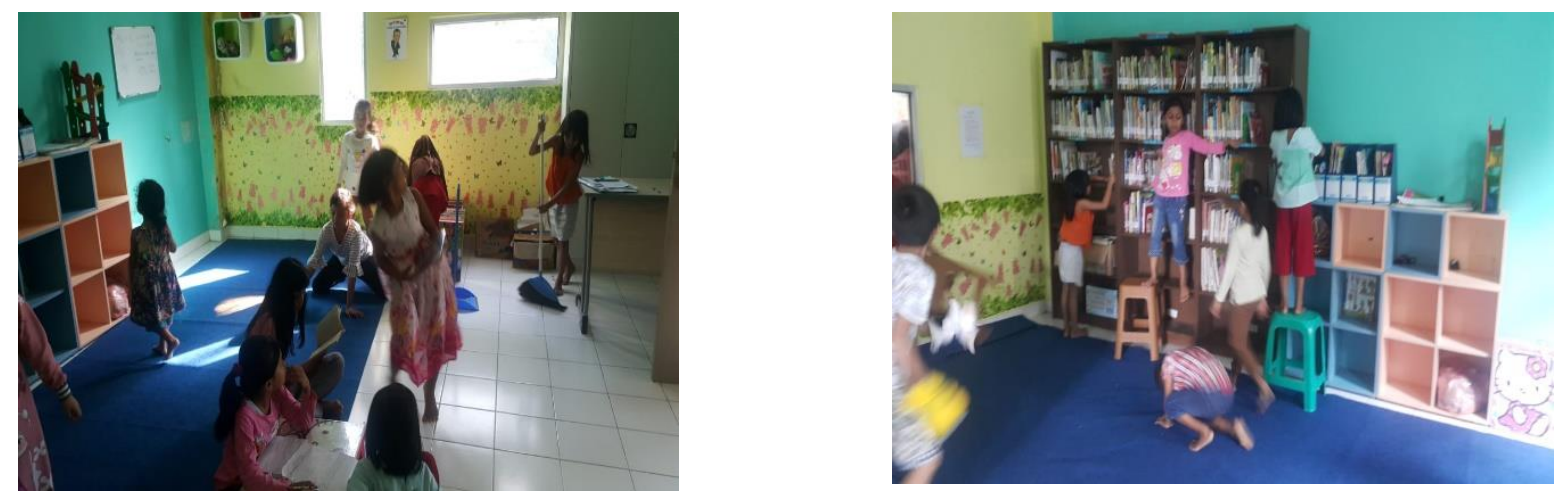

Gambar 1. Aktivitas anak-anak di Ceribel

Anak-anak yang datang ke Ceribel umumnya tinggal di Blok 5 tempat Ceribel berada. Usia mereka empat hingga empat belas tahun (TK hingga SMP). Karena Ceribel dibuka selain untuk melayani pengunjung juga untuk mempersiapkan anak-anak berlomba, mereka juga mendapat bimbingan untuk membaca dan menulis dari mahasiswa pendamping. Anak-anak tampak senang dan menganggap Ceribel sebagai rumah kedua tempat mereka bermain, mengobrol, dan membaca, baik membaca mandiri bersuara maupun membaca di dalam hati. Mereka bebas membaca buku apa saja tanpa beban tugas dan tanpa keharusan menyelesaikan buku tersebut bila dirasakan membosankan atau terlalu sulit (Hidayah, 2017).

Anak-anak perempuan khususnya juga secara spontan melakukan pekerjaan seperti di rumah sendiri, yaitu membersihkan jendela dan menyapu lantai. Anak laki-laki beberapa kali bertengkar, saling mengejek atau berebut mainan hingga salah satu menangis dan meninggalkan Ceribel. Namun, semua itu dapat ditangani sehingga tidak berpengaruh besar bagi kenyamanan belajar dan bermain di Ceribel bagi pengunjung lainnya.

Dari pengamatan, masih tampak anak yang belum lancar membaca meskipun sudah duduk di bangku kelas III dan IV SD. Hal itu terlihat ketika mereka membaca di Ceribel. Mereka membaca dengan bersuara, tetapi masih terbata-bata. Gambaran anak-anak ini mengonfirmasi hasil Asesmen Kompetensi Siswa Indonesia (AKSI) Pusat Penilaian Pendidikan (Puspendik) Kemendikbud tahun 2016 bahwa sebanyak 46,83\% siswa kelas IV SD kurang mampu membaca. Begitu pula, temuan bahwa tingkat literasi membaca siswa kelas awal (1-3) SD masih rendah (Adrian \& Tim Inovasi, 2018). Dengan dibukanya akses Ceribel, anak-anak dapat berlatih memperlancar membaca buku apa saja yang mereka sukai. Buku yang paling banyak dibaca adalah buku cerita atau komik. Mereka tertarik pada bacaan yang bergambar. Mereka membolak-balikkan buku, lalu mengembalikan ke rak, dan mencari lagi buku yang menarik perhatian dan keingintahuan mereka tentang sesuatu. Sementara ada anak yang membaca, anak lainnya bermain APE secara bersamasama.

Anak-anak yang tinggal di rusunawa ini tidak mempunyai komunitas berteman selain teman satu blok atau satu lantai tempat tinggal mereka. Kebiasaan mereka sepulang sekolah adalah tidak melakukan apa pun di rumah, sesekali mengobrol di lantai bawah, jajan di warung-warung atau mengobrol di tempat-tempat tertentu di lingkungan rusunawa. Setelah mengetahui Ceribel dibuka 
untuk pengunjung, mereka datang dan menemukan kesenangan dengan membaca dan bertemu dengan anak-anak lainnya. Jika mereka di rumah tidak dapat membaca karena ketiadaan buku hiburan, misalnya, mereka dapat membacanya di Ceribel. Perlahan-lahan dengan datang, membaca, dan belajar bersama-sama, anak-anak dibiasakan membaca sebagai suatu kebutuhan, bukan keterpaksaan.

Pembiasaan membaca buku akan mengantar mereka untuk gemar membaca, suatu keterampilan hidup sepanjang hayat yang sangat baik dipupuk sejak anak-anak. Akan tetapi, apabila keinginan membacanya tidak terlampiaskan pada masa itu, akan sulit untuk dirangsang. Anak perlu distimulus dengan membiasakan mereka banyak membaca jenis bacaan selain buku pelajaran karena melalui bacaan jenis itu, anak akan belajar karakter positif yang dapat tertanam dalam dirinya. Jika orang tua tidak dapat memenuhi kebutuhan akan bacaan, kehadiran Ceribel menjadi solusi yang tepat bagi anak-anak Rusunawa Muara Baru untuk dapat memperoleh bacaan yang bermutu. Kebiasaan membaca sejak anak-anak akan terbawa ke dalam kehidupan masa dewasa dan berdampak kesuksesan hidup yang lebih baik (Rohman, 2017)

Upaya mengembangkan literasi selain melalui pelayanan peminjaman buku juga mengadakan lomba yang melatih kreativitas mereka. Semula anak-anak tidak termotivasi untuk mengikuti lomba. Mereka hanya mau bermain dan membaca. Namun, dengan bimbingan secara rutin di setiap pertemuan, anak-anak termotivasi untuk belajar mengarang. Anak-anak dibimbing untuk belajar mengungkapkan pengalaman dirinya tinggal di rusunawa. Karena mengarang merupakan proses, anak-anak mengarang setahap demi setahap hingga mampu menuangkan cerita dalam bahasa mereka. Mahasiswa sebagai pembimbing mengajarkan bagaimana menata pikiran dalam sebuah karangan. Akhirnya, terkumpul 27 karangan yang cukup bervariasi dari segi isi dan panjang-pendek karangan. Dari karangan yang terkumpul, dipilih tiga karangan terbaik sesuai dengan kriteria penilaian yang telah ditetapkan dalam lembar penilaian.

Semangat kompetisi lainnya yang dibangun adalah lomba puzzle dan menggambar dan mewarnai, seperti pada Gambar 2 dan Gambar 3. Untuk kedua jenis lomba ini, anak-anak dibagi dalam dua kategori berdasarkan usia, yaitu TK sampai III SD dan IV SD sampai SMP. Berbeda dengan lomba mengarang yang dituntaskan hasil karangannya di Ceribel pada pertemuan terakhir pendampingan, lomba puzzle, menggambar, dan mewarnai diadakan pada hari khusus lomba. Peserta lomba puzzle ada 11 anak, sedangkan menggambar dan mewarnai 23 orang. Penilaian lomba mengunakan lembar penilaian.

Menggambar dan mewarnai yang dihasilkan didominasi oleh gambar rumah dan pemandangan, seperti laut dan gunung dengan permainan warna yang bervariasi. Yang menarik dari para peserta lomba ini adalah mereka sangat bersemangat dan tidak sabar menyelesaikan lombanya. Suasana lomba berlangsung kondusif dan meriah. Pada lomba puzzle, teman yang menunggu giliran untuk menata puzzle memberi dorongan dengan cara menyemangati. Dalam lomba menggambar dan mewarnai, anak-anak menggunakan pensil berwarna secara bersama-sama dan bergantian. 


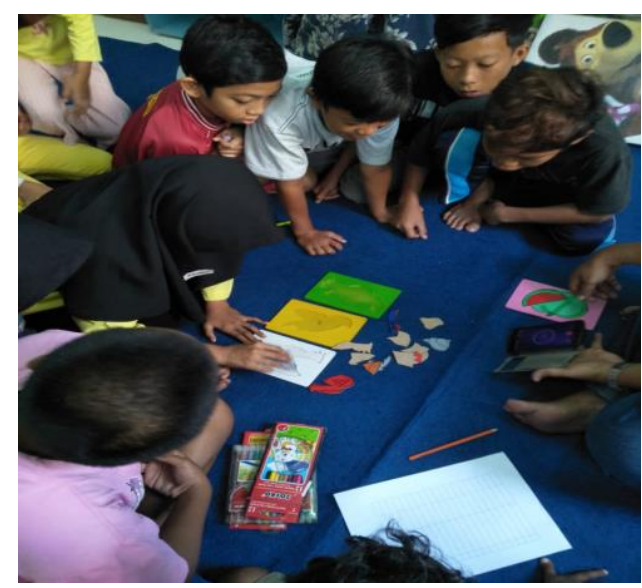

Gambar 2. Suasana lomba puzzle

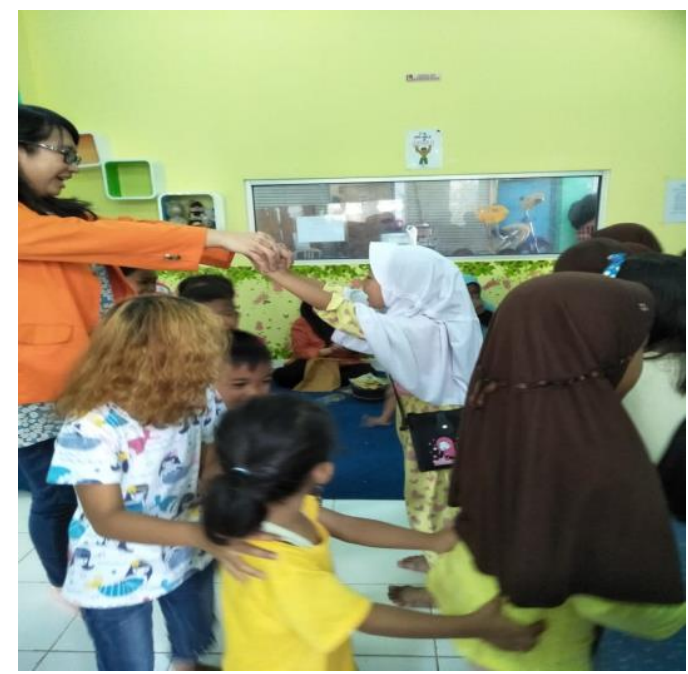

Gambar 4. Suasana bermain setelah lomba

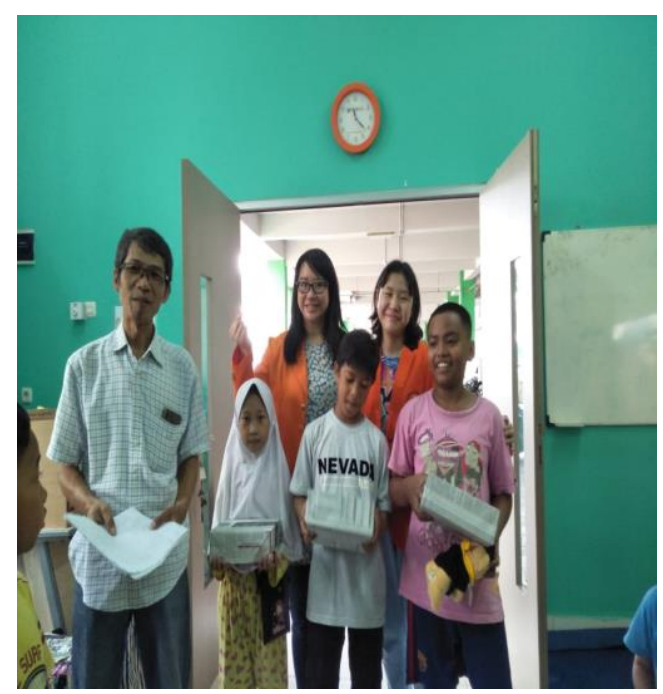

Gambar 5. Pemenang lomba puzzle

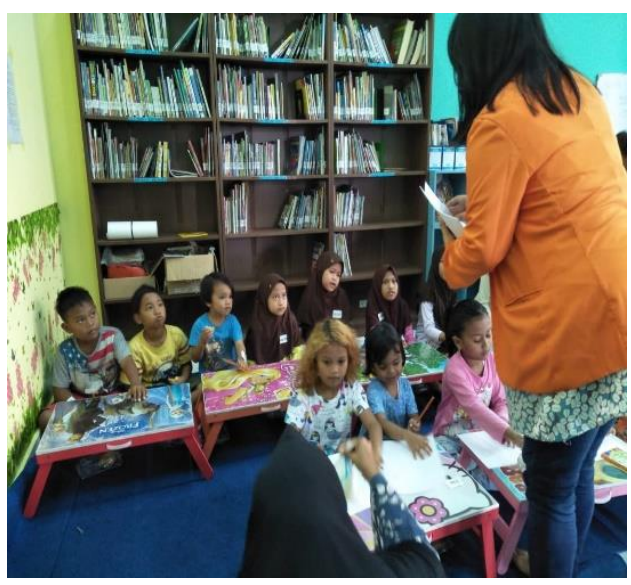

Gambar 3. Suasana lomba gambar 
Literasi yang digerakkan di Rusunawa Muara Baru cukup menarik bagi anak-anak dan remaja. Setiap waktu buka Ceribel, mereka datang untuk membaca dan mempersiapkan lomba. Ketika lomba mereka juga bersemangat untuk menang. Semangat literasi ini perlu dipupuk dengan kegiatan literasi berkelanjutan. Karena untuk menjadi insan literat dibutuhkan proses panjang hingga sepanjang hayat (Gambar 3 dan Gambar 4).

Pada dua hari terakhir pelayanan Ceribel, pengunjung yang hadir dibagikan kuesioner untuk memberikan umpan balik tentang kegiatan di Ceribel dan keberlanjutan kegiatan. Delapan belas anak yang mengisi kuesioner mengakui senang dengan adanya Ceribel di lingkungan rusunawa. Ceribel bermanfaat bagi responden sebagai tempat belajar untuk menjadi pintar (71\%), tempat berkumpul (18\%), tempat mengisi waktu kosong dan mencari ketenangan, masing-masing 6\% (Grafik 1). Data ini memperlihatkan bahwa responden menganggap Ceribel sebagai sumber informasi dan sumber belajar. Ceribel diyakini mampu membuat mereka menjadi lebih pintar, menambah pengetahuan dan informasi, tetapi juga sebagai sumber hiburan. Membaca menjadikan anak-anak lebih pintar senada seperti diungkap Antasari (2016).

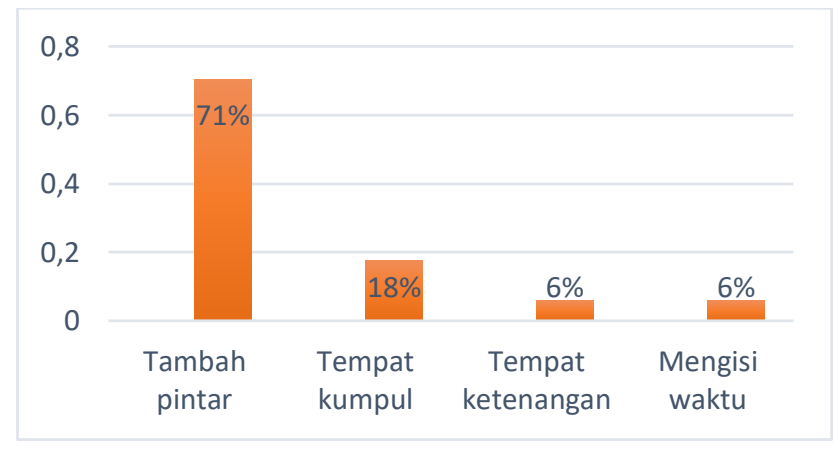

Grafik 1. Manfaat Ceribel

Ceribel menjadi tempat untuk menjadikan anak-anak pintar. Karena itu, responden anak-anak mengakui datang ke Ceribel untuk belajar (59\%), menulis (24\%), membaca (12\%), tetapi ada juga yang tidak mengetahui mau melakukan apa (6\%) (Grafik 2). Menulis dan membaca terungkap dalam umpan balik ini karena anak-anak datang ke Ceribel untuk belajar menulis dan dapat mengikuti lomba. Dengan demikian, ada tujuan positif yang hendak dicapai anak-anak. Ketika ditanyakan kegiatan apa yang diinginkan di Ceribel, responden menjawab belajar membaca (53\%), bimbingan belajar (41\%), dan seminar (6\%) (Grafik 2).

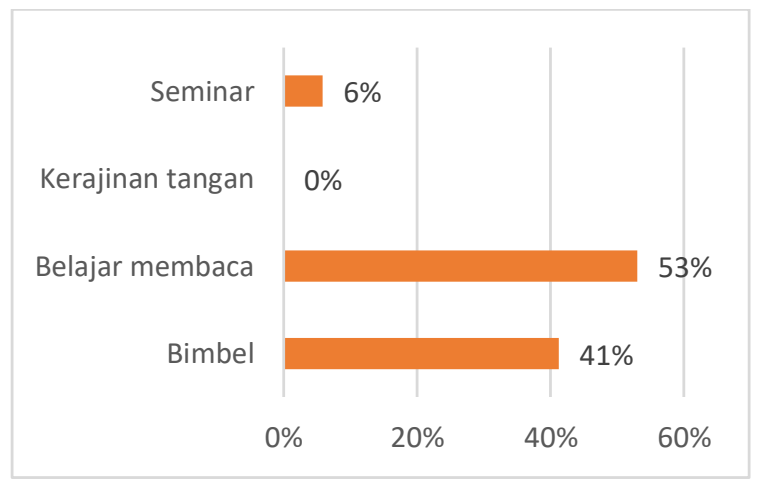

Grafik 2. Kegiatan yang diharapkan

Data tersebut menunjukkan bahwa separuh lebih responden membutuhkan pembimbingan dan pendampingan dalam pelajaran sekolah. Responden masih ada yang belum lancar membaca 
meskipun sudah duduk di bangku kelas III dan IV SD. Fakta itu mendukung hasil Asesmen Kompetensi Siswa Indonesia (AKSI) Pusat Penilaian Pendidikan (Puspendik) Kemendikbud (2016) bahwa tingkat literasi membaca siswa kelas awal (I-III) masih rendah (Adrian \& Tim Inovasi, 2018). Dengan dibukanya sentra belajar Ceribel, anak-anak dapat berlatih memperlancar membaca.

Membaca buku sebagai keterampilan hidup harus terus-menerus dilakukan sepanjang usia anak sampai menjadi kebiasaan dan sampai tumbuh minat yang tinggi untuk membaca. Akan tetapi, apabila keinginan membacanya tidak terlampiaskan pada masa anak-anak, minat membaca akan sulit untuk dirangsang pada usia yang sudah lebih dari usia sekolah. Karena itu, lingkungan yang mendukung untuk membaca dapat membantu merangsang minat anak-anak. Kehadiran Ceribel merupakan solusi yang tepat bagi anak-anak Rusunawa Muara Baru untuk dapat memperoleh manfaat yang besar dari kegiatan membaca. Hal ini memperlihatkan bahwa literasi menganut prinsip berkesinambungan, perlu terus-menerus dibina dan dilakukan, dan pastinya melibatkan orang lain, seperti keluarga dan masyarakat setempat (Kemendikbud, 2017).

Selain membaca, dari Grafik 2 tampak bahwa bimbingan belajar juga dibutuhkan responden. Ceribel dapat menjadi tempat belajar yang menyenangkan jika kebutuhan sebagai tempat belajar membaca dan bimbingan belajar terpenuhi. Sebagai sarana penunjang pembelajaran di sekolah, Ceribel dapat berperan maksimal dalam mendukung keberhasilan prestasi siswa di sekolah.

Ceribel pada masa libur sekolah telah dirasakan manfaatnya bagi anak-anak Rusunawa Muara Baru, khususnya warga Blok 5. Sebanyak $100 \%$ responden menyatakan ingin datang kembali meskipun bukan saat liburan sekolah. Mereka (94\%) juga mengakui akan mengajak teman untuk datang ke Ceribel pada masa mendatang. Waktu operasional Ceribel yang diinginkan responden adalah setiap hari (42\%), Sabtu (32\%), Senin sampai Jumat (21\%), dan Minggu (5\%) (Grafik 3). Pilihan terbanyak, yaitu dibuka setiap hari, memperlihatkan bahwa mereka ingin setiap saat bisa datang ke Ceribel.

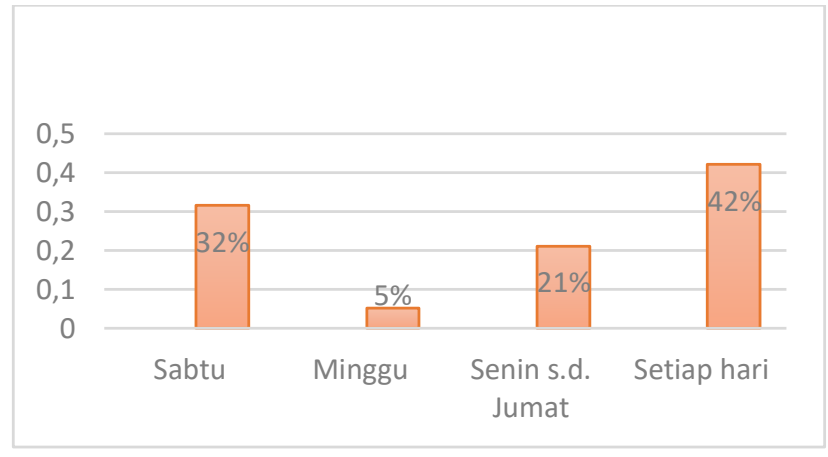

Grafik 3. Waktu buka Ceribel

Responden yang mewakili anak-anak di Rusunawa Muara Baru senang mengisi liburan di Ceribel. Mereka juga menaruh harapan kesenangan tersebut tidak sampai di situ saja. Akan tetapi, perlu direnungkan beberapa hal demi keberlanjutan Ceribel bagi anak-anak. Pertama, Ceribel belum memiliki sukarelawan sebagai sumber daya manusia yang berkomitmen mengelola Ceribel sebagai sentra belajar anak-anak. Hal ini disebabkan pengelola Ceribel adalah ibu-ibu rumah tangga yang sibuk dengan urusan rumah tangga. Komitmen mereka untuk melayani buka-tutup Ceribel masih rendah. Kedua, Ceribel belum banyak memiliki kegiatan yang berorientasi pada anak-anak dan remaja. Selama ini kegiatan masih didominasi untuk para ibu dengan programprogram kewirausahaan atau parenting. Ketiga, Ceribel belum menarik perhatian para remaja yang duduk di bangku SMA atau kuliah. Hal ini disebabkan para remaja tersebut masih sulit untuk dikumpulkan karena kesibukan di sekolah dan kegiatan ekstrakurikuler. Keempat, Ceribel masih 
kurang dikenal di luar Blok 5. Untuk dapat dikenal, bukan hanya promosi dari mulut ke mulut, melainkan Ceribel juga perlu menarik perhatian pengunjung. Untuk dapat menarik perhatian pengunjung, dapat melalui pelayanan yang ramah dan bersahabat, aneka koleksi bacaan yang disediakan, dan jenis kegiatan yang disesuaikan dengan kesenangan anak-anak dan remaja.

\section{KESIMPULAN DAN SARAN}

Kegiatan literasi yang telah dilakukan di Rusunawa Muara Baru barulah tahap awal menggerakkan literasi baca-tulis dengan mengajak anak-anak untuk datang dan memanfaatkan koleksi yang ada di Ceribel. Meskipun demikian, Ceribel telah menarik perhatian anak-anak rusunawa sebagai sentra belajar. Interaksi yang terjalin di antara anak-anak di rusunawa ini bermanfaat untuk menumbuhkan rasa berbagi dan bertolerasi, juga jiwa berkompetisi untuk menjadi lebih unggul dari yang lain. Anak-anak datang untuk membaca dan melakukan kegiatan positif di Ceribel. Dengan demikian, kegiatan literasi ini dapat dikatakan efektif mengajak anak-anak untuk memanfaatkan Ceribel sebagai ruang publik. Agar Ceribel dapat terus menggugah minat baca anak-anak rusunawa, disarankan pengurus Ceribel dapat lebih aktif menghidupkan Ceribel mengingat anak-anak perlu dibiasakan sejak dini untuk menyukai membaca. Pengurus sukarelawan yang berkomitmen tinggi dapat dipilih dari kalangan remaja yang memiliki waktu untuk mengembangkan Ceribel. Dengan adanya pengurus yang berkomitmen diharapkan Ceribel bukan menjadi gudang buku yang tidak tersentuh untuk dibaca, melainkan menjadi ruang yang dinamis dengan berbagai kegiatan berorientasi pada peningkatan literasi dan budaya baca-tulis.

\section{REFERENSI}

Adrian, O. \& Tim Inovasi. (2018). Wartabalitbang. Indonesia, Bisa! 2, 16-17.

Antasari, I.W. (2016). Dukungan orang tua dalam membangun literasi anak. Edulib, 6(2).

Asdam, B. (2015). Minat baca dan promosi perpustakaan sebagai sarana mendekatkan masyarakat pada perpustakaan. Jupiter, XIV(1), 32-37.

Atmazaki dkk. (2017). Panduan Gerakan Literasi Nasional. Jakarta: Kementerian Pendidikan dan Kebudayaan.

Chairunnisa. 2017. Pengaruh literasi membaca dengan pemahaman bacaan (Penelitian survei pada mahasiswa STKIP Kusumanegara Jakarta). Tuturan, 6(1), 745-756.

Hidayah, L. (2017). Implementasi budaya literasi di sekolah dasar melalui optimalisasi perpustakaan: Studi kasus di Sekolah Dasar Negeri di Surabaya. Ju-Ke, 1(2). 48-58.

Kemendikbud. (2017).Peta jalan gerakan literasi nasional. Jakarta: Kementerian Pendidikan dan Kebudayaan.

Rohman, S. (2017). Membangun budaya membaca pada anak melalui program gerakan literasi sekolah. Terampil Jurnal Pendidikan dan Pembelajaran Dasar, 4(1),151-173.

Sukorini, D. (2007). Pengelolaan pusat sumber belajar pada Pusdiklat SDM Kesehatan Departemen Kesehatan Republik Indonesia. Jurnal Teknodik, 21(XI).

Sutarno, N. (2006). Perpustakaan dan Masyarakat. Jakarta: Sagung Seto.

Yanto, A., Rodiah, S., \& Lusiana, E. (2016). Model aktivitas gerakan literasi berbasis komunitas di sudut baca Soreang. Jurnal Kajian Informasi \& Perpustakaan, 2(1),107-118. 